\title{
Thalassemia Alfa Mayor dengan Mutasi Non-Delesi Heterozigot Ganda
}

\author{
Dina Muktiarti*, Pustika Amalia Wahidiyat*, Ita M. Nainggolan**, Iswari Setianingsih**
}

\begin{abstract}
Seorang anak perempuan berusia 3 tahun dengan gejala klinis anemia berat, hepatosplenomegali, dan memerlukan tranfusi darah teratur. Gejala klinis telah timbul saat pasien berusia 3 bulan. Hapusan darah tepi menunjukkan gambaran hipokrom, mikrositosis, dan anisopoikilositosis. Kadar $\mathrm{HbA} 2$ normal, $\mathrm{HbF}$ sedikit meningkat, dan terdapat HbBart's. Ayah dan ibu memiliki gambaran hematologis yang mendekati normal. Analisis DNA menunjukkan dua mutasi non-delesi (mutasi titik) pada gen globin a2 yaitu pada kodon 59 (GGC glisin $_{\rightarrow}$ GAC $^{\text {aspartat}}$ ) dan IVS2-nt142 (AG $\rightarrow$ AA). Kasus ini adalah kasus pertama yang ditemukan di Departemen Ilmu Kesehatan Anak RS. Dr. Cipto Mangunkusumo Jakarta yang mempunyai mutasi heterozigot ganda pada kodon 59 dan IVS2-nt142. Gejala klinis thalassemia mayor diakibatkan adanya mutasi kodon 59 yang menghasilkan varian hemoglobin yang tidak stabil (HbAdana) disertai adanya mutasi non-delesi pada IVS2-nt142 yang menyebabkan proses mRNA yang tidak normal.
\end{abstract}

Kata kunci: thalassemia alfa, mutasi non-delesi, kodon 59, IVS2-nt142

ๆ halassemia merupakan penyakit genetik sintesis hemoglobin yang menimbulkan masalah kesehatan yang cukup penting di negara berkembang karena angka kejadiannya yang tinggi serta konsekuensi jangka panjang yang harus diderita pasiennya. ${ }^{1-4}$ Thalassemia alfa $(\alpha)$ disebabkan berkurang atau tidak adanya sintesis rantai $\alpha$ yang disebabkan oleh mutasi gen globin $\alpha$ baik berupa delesi gen maupun non-delesi (mutasi titik). 11

Alamat korespondensi:

Dr. Pustika Amalia Wahidiyat, SpA, Dina Muktiarti, Divisi HematologiOnkologi Departemen Ilmu Kesehatan Anak FKUI-RSCM Jl. Salemba No.6 Jakarta 10430 021-31901170

Ita M. Nainggolan, Iswari Setianingsih, Lembaga Biologi Molekuler Eijkman, Jakarta
Angka kejadian thalassemia $\alpha$ cukup bervariasi, namun cukup tinggi di Asia Tenggara dan Cina Selatan. ${ }^{9,12}$ Frekuensi pembawa sifat berdasarkan parameter indeks sel darah merah di Indonesia berkisar 2,6\%-11\%.

Gambaran klinis pada thalassemia $\alpha$ ditentukan oleh jumlah rantai $\alpha$ yang ada, jenis mutasi yang terjadi, atau jenis gen $\alpha$ yang terkena. ${ }^{13}$ Gambaran klinis pasien dengan mutasi non-delesi yang menghasilkan rantai globin alfa atau hemoglobin tidak stabil, biasanya lebih parah dibandingkan dengan pasien dengan mutasi delesi gen. ${ }^{9}$ Pemeriksaan analisis DNA sangat penting dilakukan untuk mengetahui jenis mutasi yang terjadi sehingga dapat diprediksi prognosis dan pengobatannya, informasi ini penting juga untuk konseling genetik. ${ }^{1-3}$ Tujuan laporan kasus ini untuk menunjukkan bahwa gambaran klinis thalassemia mayor dapat disebabkan oleh adanya mutasi non-delesi gen globin $\alpha$ heterozigot ganda. 
Sari Pediatri, Vol. 8, No. 3, Desember 2006

\section{Kasus}

Seorang anak perempuan, berusia 1 tahun 8 dirawat untuk pertama kali di Departemen Ilmu Kesehatan Anak RS Dr. Cipto Mangunkusumo (IKA RSCM) dengan keluhan utama terlihat pucat sejak usia 3 bulan disertai lemas dengan perut yang tampak membesar. Tidak ditemukan adanya perdarahan. Saat itu menunjukkan kadar $\mathrm{Hb} 3,4 \mathrm{~g} / \mathrm{dL}$ dan pasien mendapatkan transfusi darah. Satu bulan kemudian, pasien tampak pucat kembali dengan $\mathrm{Hb} 6 \mathrm{~g} / \mathrm{dL}$ sehingga mendapat transfusi lagi. Setelah itu pasien tidak pernah kontrol dan hanya menjalani pengobatan alternatif dengan jamu. Pada usia 1 tahun 8 bulan, orangtua pasien membawa pasien berobat ke RSCM.

Pasien adalah anak pertama dari dua orang bersaudara, lahir spontan, cukup bulan dengan berat lahir 2600 gram, langsung menangis. Adik pasien saat itu berusia 1 bulan dan sehat. Tidak terdapat riwayat abortus dalam keluarga ini. Ayah berusia 30 tahun, suku Betawi, dan ibu berusia 33 tahun, suku Sunda-Batak.

Pemeriksaan fisis saat awal perawatan anak tampak sakit sedang, sadar, tidak sesak, tidak sianosis, dan tampak pucat. Berat badan $6,8 \mathrm{~kg}\left(<\mathrm{P}_{3} \mathrm{NCHS}\right)$, tinggi badan $70 \mathrm{~cm}\left(<\mathrm{P}_{3} \mathrm{NCHS}\right)$; kesan gizi kurang. Tanda vital baik tidak didapatkan fasies Cooley. Konjungtiva pucat, sklera tak ikterik. Telinga, hidung, dan tenggorok dalam batas normal. Pada jantung dan paru dalam, didapatkan bising ejeksi sistolik di seluruh ostia. Paru normal, perut datar, lemas, terdapat hepatosplenomegali. Akral hangat, perfusi perifer cukup.

Pada pemeriksaan darah tepi ditemukan hemoglobin 3,6 g/dL, hematokrit 10 vol\%, leukosit $11.700 / \mu \mathrm{L}$, trombosit $141.000 / \mu \mathrm{L}$, hitung jenis (\%): basofil 1, eosinofil 1, batang 3, segmen 75 , limfosit 18, monosit 2. Hapusan darah tepi menunjukkan gambaran anisopoikilositosis. Pada analisis $\mathrm{Hb}$ didapatkan kadar $\mathrm{HbF} 1,2 \%$ (normal: $<2 \%$ ), HbA2 2,6\% (normal: 2,5-3,5\%). Hasil aspirasi sumsum tulang menunjukkan hiperaktif sistem eritropoetik.

Pada saat itu ditegakkan diagnosis tersangka thalassemia, gagal tumbuh, gizi kurang, perawakan pendek. Selanjutnya pasien kontrol teratur di Poliklinik Thalassemia dan mendapatkan transfusi darah teratur setiap bulannya, asam folat, dan vitamin E. Analisis $\mathrm{Hb}$ pasien beserta kedua orangtuanya tertera pada Tabel 1 dan Gambar 1.

Hasil analisis DNA di Lembaga Eijkman Jakarta menunjukkan bahwa pasien mempunyai mutasi heterozigot ganda yaitu mutasi titik pada kodon 59 (GGC glisinàGAC aspartat)dan mutasi titik IVS2-nt142 (AGàAA). Mutasi titik kodon 59 diturunkan dari ayahnya dan mutasi titik IVS2-nt142 diturunkan dari ibunya (Gambar 2, 3, 4 ).

Diagnosis akhir pasien adalah thalassemia a dengan mutasi heterozigot ganda (mutasi titik pada kodon 59 dan mutasi titik IVS2-nt142).

Tabel 1. Hasil pemeriksaan pasien dan kedua orangtuanya

\begin{tabular}{lcccc}
\hline Laboratorium & Anak & Ayah & Ibu & $\begin{array}{c}\text { Nilai normal } \\
\text { Dewasa/3 tahun }\end{array}$ \\
\hline Hb (g/dL) & 4,9 & 13,5 & 13,5 & $12-18 / 10-14$ \\
$\mathrm{MCV}(\mathrm{fl})$ & 71,7 & 78,0 & 79,3 & $80-97 / 75-87$ \\
$\mathrm{MCH}(\mathrm{pg})$ & 23,6 & 26,5 & 26,7 & $26-32 / 24-30$ \\
$\mathrm{MCHC}(\mathrm{g} / \mathrm{dL})$ & 32,9 & 33,9 & 33,7 & $31-36 / 31-37$ \\
$\mathrm{RDW}(\%)$ & 29,0 & 15,8 & 14,4 & $11,5-14,5$ \\
$\mathrm{HbA2}(\%)$ & 2,6 & 2,5 & 2,7 & $2,5-3,5$ \\
$\mathrm{HbF}(\%)$ & 2,4 & 0,5 & 0,0 & $<1 \%$ \\
Jenis Hb & A,F,A2, Bart's & A,F,A2 & A,F,A2 \\
Hapusan darah tepi & Mikrositik-hipokrom, & Mikrositik-hipokrom & Mikrositik-hipokrom & \\
& aniso-poikilositosis, & ringan, anisositosis & ringan, anisositosis & \\
& sel target, sel kodosit, & ringan,sel tear drops & ringan, sel elips & \\
& sel eritrosit muda dan & (sangat jarang) & (sangat jarang) & \\
& fragmentosit & & & \\
\hline
\end{tabular}

Keterangan: $\mathrm{Hb}=$ hemoglobin, $\mathrm{MCV}=$ mean corpuscular volume, $\mathrm{MCH}=$ mean corpuscular hemoglobin, $\mathrm{MCHC}=$ mean corpuscular hemoglobin concentration, $\mathrm{RDW}=$ red cell distribution width 


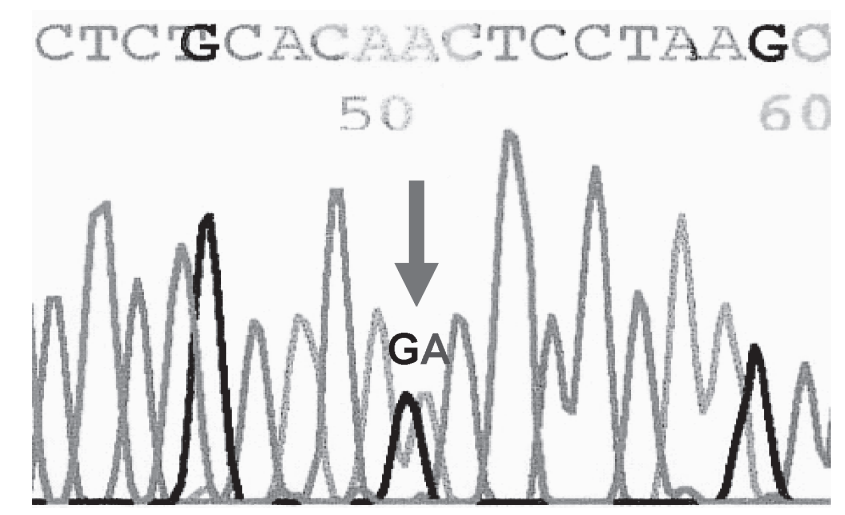

Gambar 3. Sekuensing gen globin a2

Ayah Ibu Pasien

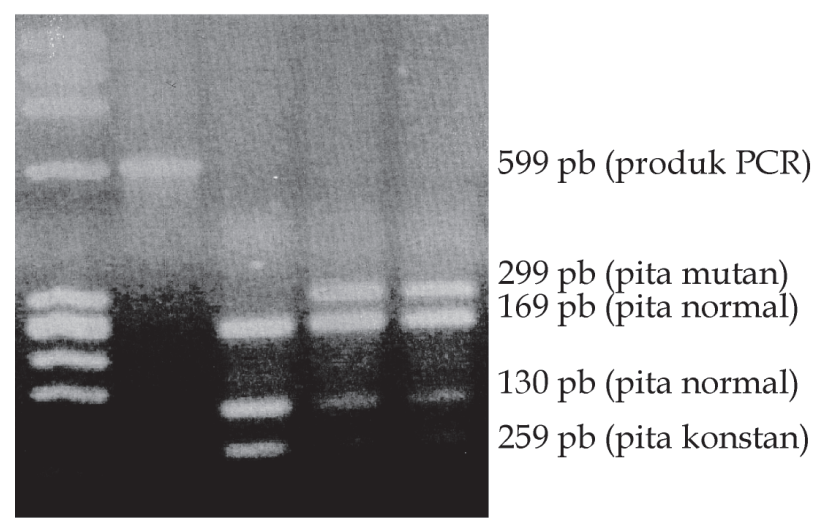

Gambar 4. PCR-RFLP: Mutasi IVS2-nt142

Akibat berkurangnya sintesis rantai $\alpha$, maka terjadi kelebihan rantai $\gamma$ dan $\beta$ yang akan membentuk tetramer $\gamma_{4}$ (HbBart's) pada masa janin dan $\beta_{4}(\mathrm{HbH})$ pada dewasa. Penyebab utama anemia pada penyakit $\mathrm{HbH}$ karena hemolisis lebih dominan di perifer dan bukan karena eritropoesis yang tidak efektif seperti yang terjadi pada thalassemia $\beta$. Hal ini disebabkan karena $\mathrm{HbH}$ dan HbBart's relatif stabil dibandingkan $\alpha_{4}$, yang menjadi tidak stabil bila ada pencetus seperti infeksi, dan zat oksidatif. Untuk itu sangat penting menghindari obat-obatan atau hal-hal yang dapat menyebabkan kejadian oksidatif dan meningkatkan hemolisis. ${ }^{1,2,5}$

Pasien thalassemia $\alpha$ dapat menunjukkan gejala thalassemia minor (trait/pembawa sifat), anemia ringan sampai sedang (thalassemia intermedia), anemia berat (thalassemia mayor) dan hydrops fetalis. Hal ini dipengaruhi oleh jenis gen $\alpha$ yang terkena $\left(\alpha_{1}\right.$ atau $\alpha_{2}$ ), tipe mutasi (delesi atau non-delesi), atau jumlah gen yang inaktif., ${ }^{8,13}$

Tipe mutasi yang dapat terjadi adalah delesi gen dan non-delesi atau mutasi titik. Delesi gen yang sering terjadi adalah delesi dua gen yaitu tipe Southeast Asian (SEA), dan delesi satu gen (delesi 3,7 kb gen globin $\alpha$, delesi 4,2 kb gen globin $\alpha$ ). ${ }^{6}$ Jenis mutasi non-delesi gen sangat banyak jumlahnya, terdapat lebih dari 100 jenis mutasi yang sudah diketahui. ${ }^{16}$ Di Asia Tenggara mutasi non-delesi yang dapat ditemukan antara lain Hb Constant Spring (kodon 142), Hb Pakse (kodon 142), Hb Quong Sze (kodon 125), Hb Suan Dok (kodon 109), Hb Adana (kodon 59), kodon 0, dan kodon $30 .^{7}$

Di Indonesia, mutasi non-delesi yang ditemukan adalah mutasi pada gen globin $\alpha 2$ yaitu di kodon 59 (Hb Adana), kodon 22 (GGC glisin $^{\text {liGGT }}{ }^{\text {glisin }}$ ), dan jenis Hb Constant Spring. Mutasi di kodon 59 ini terdeteksi pada 3 orang etnis Jawa. ${ }^{8}$

Pasien yang mengalami mutasi non-delesi gen mempunyai gejala yang lebih berat bila dibandingkan dengan mereka yang mengalami mutasi delesi gen, karena adanya rantai globin alfa atau hemoglobin yang tidak stabil.

Berdasarkan jumlah gen yang inaktif maka dapat terdapat empat kelompok besar thalassemia $\alpha$ yaitu silent carrier (delesi 1 gen), trait thalassemia $\alpha$ (delesi 2 gen), penyakit $\mathrm{HbH}$ (delesi 3 gen), dan hydropsfetalis/ thalassemia $\alpha$ mayor (delesi 4 gen). Pada delesi 1 gen dan 2 gen pasien tidak memiliki gejala klinis. Diagnosis ditegakkan secara tidak sengaja dan biasanya terdapat gambaran hipokrom dan mikrositik. ${ }^{2,3}$

Gambaran penyakit $\mathrm{HbH}\left(\beta_{4}\right)$ adalah anemia hemolitik, ikterus, splenomegali, transfusi darah biasanya tidak diperlukan kecuali terdapat penyakit lain. Penelitian terhadap populasi Cina mendapatkan hanya sekitar $24 \%$ dari pasien penyakit $\mathrm{HbH}$ yang mempunyai gejala seperti anemia dan ikterus dan sebagian besar (76\%) diagnosis ditegakkan secara tidak sengaja, seperti saat pemeriksaan kesehatan saat masuk bekerja atau saat hamil. Kejadian gagal tumbuh pada anak terdapat pada $13 \%$ kasus dan transfusi darah hanya dibutuhkan pada $46 \%$ pasien.

Delesi 4 gen akan berakibat fatal dan dikenal sebagai thalassemia $\alpha$ homozigot atau sindrom hidrops fetalis HbBart's. Janin tanpa gen globin $\alpha$ akan menderita anemia berat, hipoksia, gagal jantung, dan hidrops fetalis. Janin dapat hidup sampai trimester ketiga dan hanya memiliki 
(b)

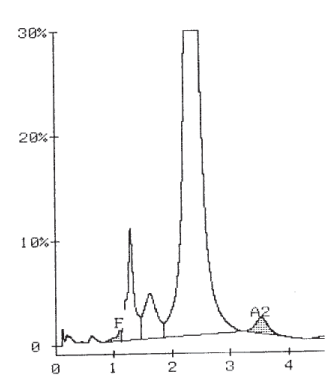

(a)

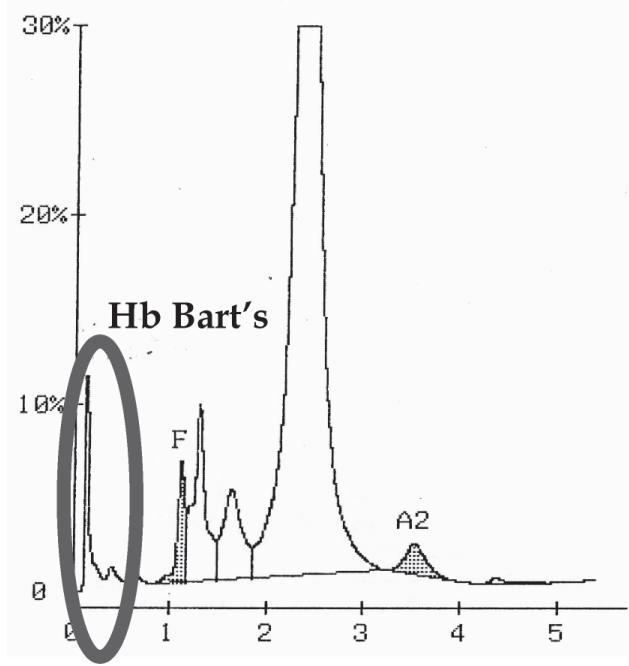

(c)

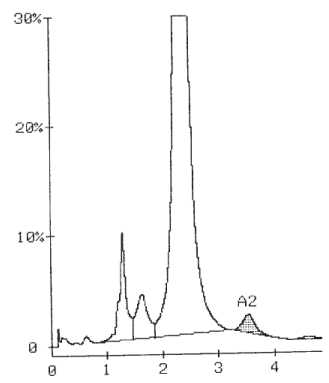

Gambar 1. Hasil elektroforesis Hb: (a) Pasien; (b) Ayah pasien; (c) Ibu pasien. Pada pasien terlihat adanya kenaikan grafik pada menit 0-1, yang menunjukkan gambaran $\mathrm{Hb}$ Bart's

\section{Diskusi}

Angka kejadian thalassemia $\alpha$ cukup tinggi di Asia Tenggara dan Cina Selatan, di Hongkong berkisar 3\%5\%, sedangkan di Thailand adalah 20\%-30\%., Setianingsih I, $\mathrm{dkk}^{8}$ menemukan frekuensi pembawa sifat thalassemia $\alpha$ di tiga daerah di Indonesia (Jawa, Sulawesi Selatan, Sumatera Selatan) 2,6\%-11\%. Di klinik genetik, Lembaga Eijkman, Jakarta didapatkan $32 \%$ kasus thalassemia $\alpha$ dari 99 kasus thalassemia yang diteliti. Latar belakang etnis yang terbesar adalah etnis Cina (69\%) dan sisanya etnis Jawa (31\%). Di Departemen Ilmu Kesehatan Anak FKUI RSCM Jakarta, Wahidiyat I (1979) menemukan 6 kasus penyakit $\mathrm{HbH}(2,7 \%)$ dan sampai saat ini tercatat 20 pasien thalassemia $\alpha(1,8 \%) .{ }^{14,15}$

Thalassemia $\alpha$ disebabkan berkurang atau tidak adanya sintesis rantai $\alpha$. Sebagian besar hemoglobin (Hb) normal pada dewasa terdiri dari $\operatorname{HbA}\left(\alpha_{2} \beta_{2}\right)$, dan hanya sedikit $\operatorname{HbA}_{2}\left(\alpha_{2} \delta_{2}\right)$ dan $\operatorname{HbF}\left(\alpha_{2} \gamma_{2}\right)$.

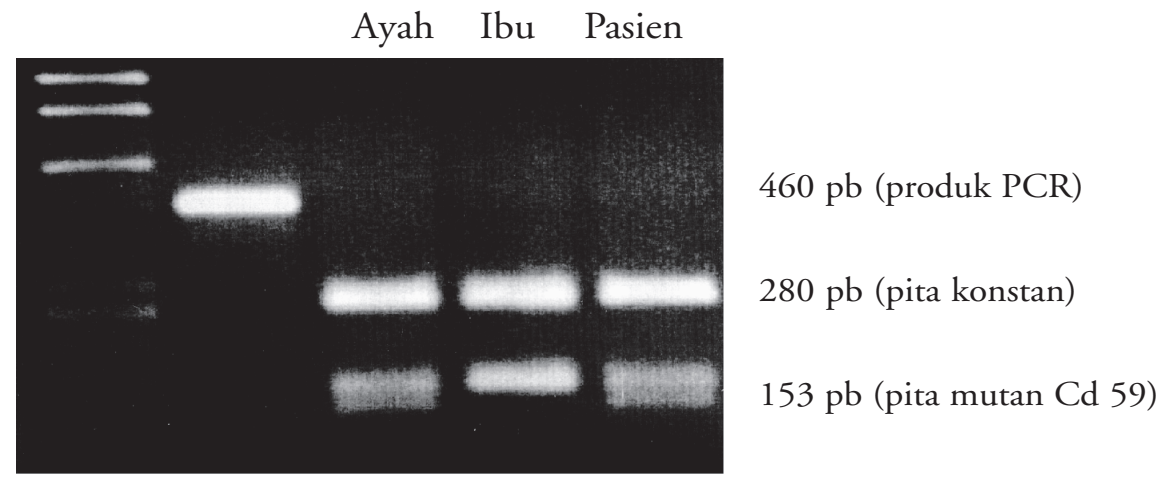

Gambar 2. PCR-RFLP: Mutasi kodon 59 (GGC ${ }^{\text {glisin }} \rightarrow$ GAC $^{\text {Aspartat }}$, Hb Adana) 
HbBart's $(\gamma 4)$. HbBart's ini sangat sulit mengantarkan oksigen ke jaringan dan tidak stabil. Bayi dapat meninggal dalam kandungan atau bila lahir bayi akan tampak sangat pucat dan terdapat edema. Bayi biasanya lahir prematur dengan rata-rata usia gestasi 31 minggu. Sampai saat ini terdapat sedikitnya enam anak yang dapat bertahan hidup. Mereka mendapatkan transfusi segera setelah lahir atau transfusi intrauterin, serta transfusi darah teratur sesudahnya dan kelasi besi. ${ }^{6}$

Pemeriksaan laboratorium yang dilakukan untuk menegakkan diagnosis thalassemia $\alpha$ adalah darah perifer lengkap ( $\mathrm{Hb}, \mathrm{MCV}$, dan $\mathrm{MCH})$, gambaran darah tepi, analisis $\mathrm{Hb}$, dan analisis DNA. Pasien thalassemia mempunyai nilai $\mathrm{MCV}$ yang rendah dan dikatakan bahwa nilai MCV $72 \mathrm{fl}$ adalah nilai yang sangat sensitif dan spesifik untuk diagnosis thalassemia. ${ }^{17}$ Suatu penelitian di Hong Kong memakai parameter MCV kurang dari $80 \mathrm{fl}$ dapat menjaring 150 pasien dan 145 di antaranya mempunyai mutasi thalassemia $\alpha$ atau $\beta$. Pada penelitian ini didapatkan 90 pasien yang mempunyai mutasi sehubungan dengan thalassemia $\alpha .{ }^{18}$ Suatu program skrining di Itali menggunakan kadar MCV $78 \mathrm{fl}$ dan $\mathrm{MCH} 27$ pg sebagai nilai batas. ${ }^{19}$ Alur diagnosis untuk thalassemia dapat dilihat pada Gambar 5.

Gambaran khas untuk $\mathrm{HbH}$ selain sel darah merah mikrositik, hipokrom, anisopoikilositosis juga adanya badan inklusi $\mathrm{HbH} .{ }^{17}$ Analisis $\mathrm{Hb}$ merupakan metode pilihan untuk identifikasi jenis $\mathrm{Hb}$ dan penggunaan teknik HPLC dapat mendeteksi varian thalassemia beta dan mendeteksi $\mathrm{Hb} \mathrm{A}$, $\mathrm{Hb}$ F, dan $\mathrm{Hb}$ abnormal seperti $\mathrm{HbS}$ dan $\mathrm{HbC}$, tapi tidak dapat mendeteksi HbBart's. Sementara itu harga alat untuk mendeteksi varian dari thalassemia $\alpha$ jauh lebih mahal. Namun, Fucharoen, $\mathrm{dkk}^{20}$ menemukan bahwa dengan menggunakan alat ini terdapat kenaikan grafik antara menit $0-1$, maka grafik tersebut merupakan gambaran HbBart's. Dengan cara ini HbBart's hanya dapat dinilai secara kualitatif saja dan tidak kuantitatif.

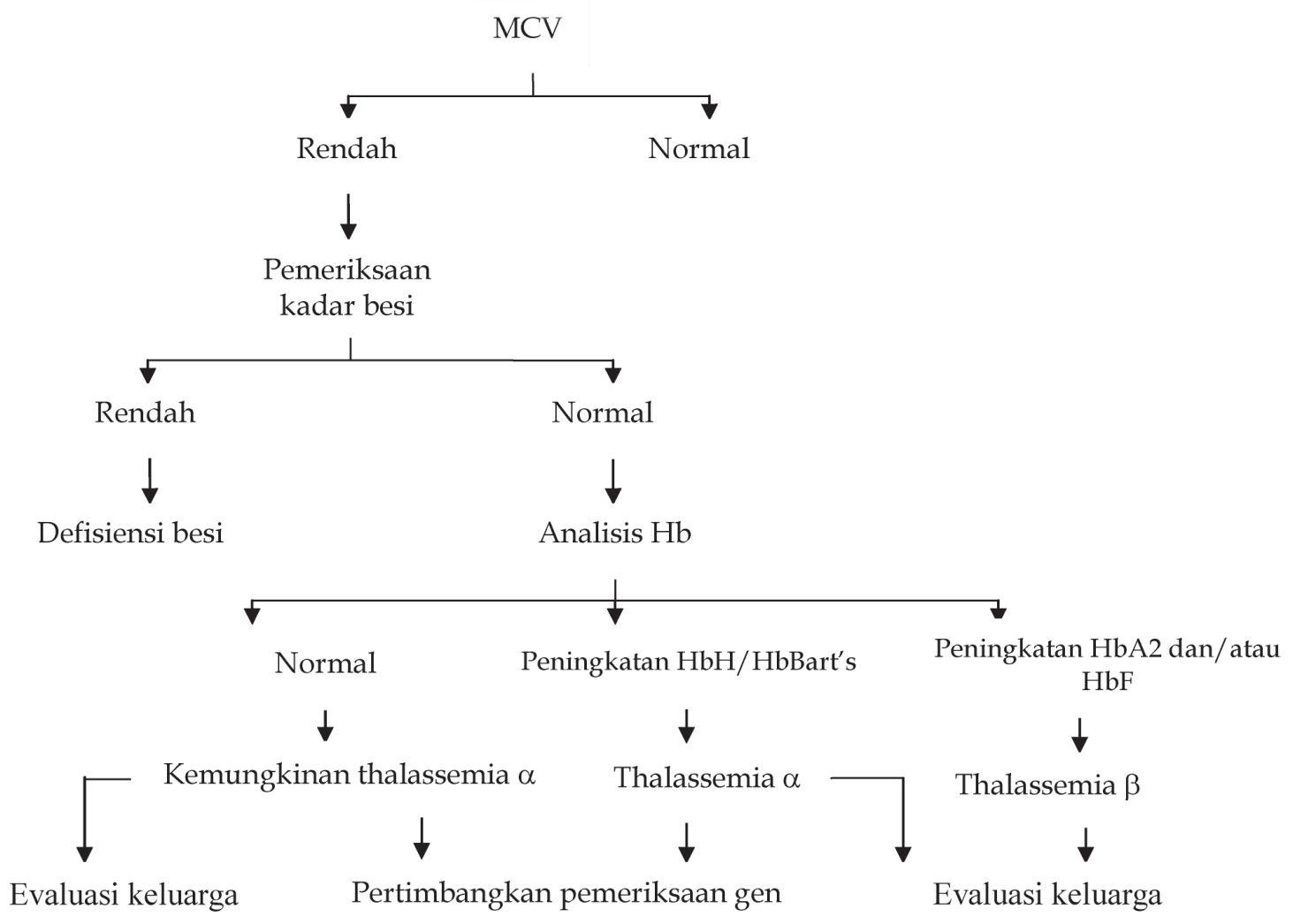

Gambar 5. Alur diagnosis thalassemia 
Diagnosis kerja pertama kali pada pasien ini adalah thalassemia berdasarkan adanya gejala pucat, pembesaran hati dan limpa, serta kadar $\mathrm{Hb}$, nilai MCV dan $\mathrm{MCH}$ yang rendah, ditemukan tanda-tanda hemolisis, namun tak ditemukan badan inklusi $\mathrm{HbH}$. Pada analisis $\mathrm{Hb}$ ditemukan kadar HbA2 normal sedangkan $\mathrm{HbF}$ sedikit meningkat. Diagnosis thalassemia $\alpha$ agak terlambat ditegakkan karena baru pada saat analisis $\mathrm{Hb}$ terakhir ditemukan adanya HbBart's, berdasarkan gambaran grafik analisis $\mathrm{Hb}$.

Analisis DNA sangat diperlukan untuk menemukan mutasi yang terjadi, karena kedua orangtuanya tidak ada yang menunjukkan pembawa sifat thalassemia $\alpha$ yang berat dengan kadar MCV mendekati nilai normal (78 dan 79,3fL). Keadaan seperti ini biasanya disebabkan oleh adanya mutasi titik. Analisis DNA menunjukkan adanya mutasi heterozigot ganda yaitu mutasi pada mutasi titik pada kodon 59 dan mutasi titik IVS2-nt142. Mutasi pada kodon 59 diturunkan dari ayah sedangkan mutasi titik IVS2-nt142 diturunkan dari ibu pasien.

Mutasi di kodon 59 mengakibatkan perubahan asam amino glisin menjadi aspartat $\left(\mathrm{GGC}^{\text {glisin }} \rightarrow\right.$ GAC aspartat) dan menghasilkan varian hemoglobin yang sangat tidak stabil. Gambaran klinis yang dapat terjadi pada mutasi ini adalah mulai dari thalassemia intermedia atau mayor, bahkan hidrops fetalis. Mutasi ini dilaporkan juga di Turki, Cina, Israel, dan Indonesia. ${ }^{8,9,21-24}$ Mutasi IVS2-nt142 mempengaruhi proses RNA (splice acceptor consensus sequence) yaitu adanya perubahan sekuens dari AG menjadi AA. Mutasi ini dilaporkan pada dua orang pasien di Argentina yaitu seorang ibu dan putrinya. Sang ibu menderita anemia, ikterus, dan hepatosplenomegali. Mutasi yang terjadi pada ibu adalah mutasi pada IVS2nt142 dan mutasi delesi dua gen. Sedangkan anaknya tidak mempunyai gejala klinis dan hanya mempunyai mutasi IVS2-nt142 saja. ${ }^{25}$

Kasus ini merupakan kasus pertama yang mempunyai mutasi heterozigot ganda pada kodon 59 dan IVS2-nt142. Gejala klinis pada pasien ini adalah thalassemia mayor diakibatkan adanya mutasi kodon 59 yang menghasilkan varian hemoglobin yang tidak stabil (HbAdana) disertai adanya mutasi titik pada IVS2-nt142.

Tatalaksana pada thalassemia $\alpha$ adalah transfusi darah merah (bila diperlukan), asam folat, dan terapi kelasi besi. Penghindaran terhadap obat-obatan yang menyebabkan oksidasi dan hemolisis seperti sulfa, obat antimalaria, dan aspirin. Selain itu perlu untuk mencegah dan mengatasi infeksi dengan baik. Transfusi sebaiknya diberikan bila kadar $\mathrm{Hb}$ sudah mencapai 9$10 \mathrm{~g} / \mathrm{dL}$ dan mencapai $\mathrm{Hb}$ pasca transfusi tidak lebih dari 13-14 g/dL. Hal ini akan menjamin pertumbuhan yang normal, menekan eritropoesis di tempat lain, dan meminimalisasi akumulasi besi. Terapi kelasi besi dengan deferioksamin dilakukan bila kadar feritin telah melebihi $1000 \mathrm{ng} / \mathrm{mL}$ dengan dosis $40-50 \mathrm{mg} / \mathrm{kg} / \mathrm{hari}$. Splenektomi diperlukan bila kebutuhan transfusi meningkat atau telah terjadi hipersplenisme. Dukungan psikologis dan sosial juga dibutuhkan pada anak yang lebih besar dan remaja. ${ }^{2,26}$

Prognosis penyakit $\mathrm{HbH}$ sangat bervariasi, namun secara umum prognosis cukup baik; banyak pasien yang dapat hidup sampai dewasa. Walaupun demikian kasus ini memberikan informasi penting, bahwa thalassemia a dapat memberikan gejala anemia berat pada masa bayi. ${ }^{2}$

Konseling genetik sangat dibutuhkan pada keluarga pasien thalassemia. Diagnosis prenatal biasanya diambil dari biopsi vilus korionik pada usia kehamilan antara minggu ke-10 dan ke- 11 atau dengan amniosintesis antara minggu ke-16 dan ke-20. Setelah usia kehamilan 20 minggu, pemeriksaan ultrasonografi dapat mendeteksi kelainan pada janin dengan sindrom hirops fetalis HbBart's. ${ }^{6}$ Pada pasien ini, dengan adanya mutasi heterozigot pada orangtuanya, maka kemungkinan untuk mendapatkan keturunan yang menderita thalassemia a sebesar yaitu $25 \%\left(\alpha^{\mathrm{Cd} 59} \alpha / \alpha^{\text {IVS2-nt142 }} \alpha\right)$, sedangkan $50 \%$ akan menjadi pembawa sifat seperti kedua orangtuanya $\left(\alpha^{\mathrm{Cd59}} \alpha / \alpha \alpha\right.$ atau $\left.\alpha \alpha / \alpha^{\text {IVS2-nt142 }} \alpha\right)$, dan $25 \%$ normal $(\alpha \alpha / \alpha \alpha)$. Adik pasien sampai saat ini tidak menunjukkan gejala klinis, namun pemeriksaan lebih lanjut untuk kemungkinan menderita thalassemia Dua hal yang menarik dari kasus ini adalah parameter indeks sel darah merah yang mendekati normal pada orang tua sebagai pembawa sifat mutasi titik thalassemia $\alpha$ dan gejala klinis yang berat pada keturunannya yang mendapat mutasi dari kedua orang tuanya. Keadaan ini memungkinkan pembawa sifat tidak terdiagnosis saat skrining antenatal.

\section{Daftar Pustaka}

1. Weatherall DJ. Fortnightly review: the thalassaemias. $\mathrm{Br}$ Med J 1997;314:1675.

2. Lo L, Singer ST. Thalassemia: current approach to an old disease. Pediatr Clin N Am 2002;49:1165-91. 
3. Weatherall DJ. ABC of clinical haematology: the hereditary anaemias. Br Med J 1997;314:492-6.

4. Gu X, Zeng Y. A review of the molecular diagnosis of thalassemia. Hematology 2002;7:203-9.

5. Chui DHK, Fucharoen S, Chan V. Hemoglobin H disease: not necessarily a benign disorder. Blood 2003;101:791800 .

6. Chui DHK, Waye JS. Hydrops fetalis caused by a-thalassemia: an emerging health care problem. Blood 1998;91:2213-22.

7. Wang W, Ma, ESK, Amy YYC, Chui DHK, Chong SS. Multiple minisequencing screen for seven Southeast Asian nondeletional a-thalassemia mutations. Clin Chem 2003;49:800-3.

8. Setianingsih I, Harahap A, Nainggolan IM. Alpha thalassemia in Indonesia: phenotypes and molecular defects. Adv Exp Med Biol 2003; 531:47-55.

9. Chen FE, Ooi C, Ha SY, Cheung BMY, Todd D, Liang $\mathrm{R}$, dkk. Genetic and clinical features of hemoglobin $\mathrm{H}$ disease in Chinese patients. N Engl J Med 2000; 343:544-50.

10. Fisher CA, Premawardhena A, De Silva S, Perera G, Rajapaksa S, Olivieri NA, dkk. The molecular basis for the thalassaemias in Sri Lanka. Br J Haematol 2003;121:662-71.

11. Villegas A, Ropero P, Gonzalez FA, Anguita E, Espinos D. The thalassemia syndromes: molecular characterization in the Spanish population. Hemoglobin 2001; 25:273-83.

12. Greenberg PL, Gordeuk V, Issaragrisil S, Siritanaratkul N, Fucharoen S, Ribeiro RC. Major hematologic disease in the developing world-new aspects of diagnosis and management of thalassemia, malarial anemia, and acute leukemia. Hematology 2001;:479-98.

13. Orkin SH, Nathan DG. The thalassemias. Dalam: Nathan DG, Orkin SH, Ginsburg D, Look AT. Nathan \& Oski's hematology of infancy and childhood. Edisi ke-6. Philadelphia: WB Saunders Company, 2003. h. 843-919.

14. Wahidiyat I. Penelitian thalassemia di Jalarta. Tesis, 1979.
15. Rekam Medis Pusat Thalassemia Departemen Ilmu Kesehatan Anak RSCM, 2004 (data tidak dipublikasi).

16. Huisman THJ, Carver MFH, Efremov GD. A syllabus of human hemoglobin variants. Augusta,USA: The Sickle cell anemia foundation 1997.

17. Clarke GM, Higgins TN. Laboratory investigation of hemoglobinopathies and thalassemias: review and update. Clin Chem 2000;46:1284-90.

18. Lau YL, Chan LC, Chan YYA, Ha SY, Yeung CY, Waye JS, dkk. Prevalence and genotypes of a- and b-thalassemia carriers in Hong Kong-implications for population screening. N Engl J Med 1997;336:1298-301.

19. Cao A, Rosatelli MC, Monni G, Galanello R. Screening for thalassemia, a model of success. Obstet Gynecol Clin N Am 2002;29:305-28.

20. Fucharoen S, Winichagoon P, Wisedpanichkij R, SaeNgow B, Sriphanich R, Oncoung W, dkk. Prenatal and postnatal diagnoses of thalassemias and hemoglobinopathies by HPLC. Clin Chem 1998;44:740-8.

21. Curuk MA, Dimovski AJ, Baysal E, Gu LH, Kutlar F, Molchanova TP, dkk. Hb Adana or alpha 2(59) (E8)Gly $\longrightarrow$ Asp beta 2, a severely unstable alpha 1-globin variant, observed in combination with the -(alpha)20.5 $\mathrm{Kb}$ alpha-thal-1 deletion in two Turkish patients. Am J Hematol 1993;44:270-5.(abstrak)

22. Altay C. Abnormal hemoglobins in Turkey. Turk J Haematol 2002;19:63-74.

23. Oron-Karni V, Filon D, Shifrin Y, Fried E, Pogrebijsky G, Oppenheim A, dkk. Diversity of a-globin mutation and clinical presentation of a-thalassemia in Israel. Am J Hematol 2000;65:196-203.

24. Chan V, Chan VWY, Tang ML, Todd D, Chan TK. Molecular defects in Hb hydrops fetalis. Br J Haematol 1997;96:224-8.

25. Noguera NI, Gonzalez FA, Davoli RA, Milani AC, Villegas A. A novel splice acceptor site mutation of the a2-globin gene causing a-thalassemia. Hemoglobin 2001;25:311-5.

26. Galanello R. A thalassemic child becomes adult. Rev Clin Exp Hematol 2003;7:4-21. 